\title{
Classification accuracy of different pork quality evaluation methods in assessment of meat with lowered drip loss
}

\author{
Krystian Tarczyński ${ }^{1}$ (D) Andrzej Zybert ${ }^{*}$ (D) Halina Sieczkowska ${ }^{1}$ (D) \\ Elżbieta Krzęcio-Nieczyporuk ${ }^{2}$ (D) Katarzyna Antosik ${ }^{2}$ (D)
}

${ }^{1}$ Siedlce University of Natural Sciences and Humanities, Faculty of Agrobioengineering and Animal Husbandry, 08-110, Siedlce, Prusa 14, Poland. E-mail: andrzej.zybert@uph.edu.pl. "Corresponding author.

${ }^{2}$ Siedlce University of Natural Sciences and Humanities, Faculty of Medical and Health Sciences, Siedlce, Poland.

ABSTRACT: This study compared the diagnostic value of pork quality evaluation methods using different $p H$ threshold values and time-points with muscle metabolites concentration threshold values measured 45 min. post mortem in assessment of meat with lowered drip loss. Samples of 100 longissimus dorsi (LD) (Landrace $\times$ Yorkshire) $\times$ Duroc fatteners were examined after slaughter for following parameters: muscle acidity in $35 \mathrm{~min}, 2 \mathrm{~h}, 3 \mathrm{~h}, 24 \mathrm{~h}$ and $48 \mathrm{~h}\left(\mathrm{pH}_{\mathrm{l}}, \mathrm{pH}_{2}, \mathrm{pH}_{3}, \mathrm{pH}_{24}\right.$ and $\left.\mathrm{pH}_{48}\right)$, colour lightness ( $\left.\mathrm{L}^{*}, a^{*}, b^{*}\right)$, meat yield after curing and thermal processing in $72{ }^{\circ} \mathrm{C}$ (technological yield), water-holding capacity (WHC) and drip loss in 48,96 and $144 \mathrm{~h}\left(D L_{48}, D L_{96}, D L_{144}\right)$. To verify the accuracy of analysed methods two groups were distinguished according to $D L_{4}$, e.g. Low $D L\left(D L_{43} \leq 4 \%\right)$ and High DL (DL $\left.>4 \%\right)$. In High

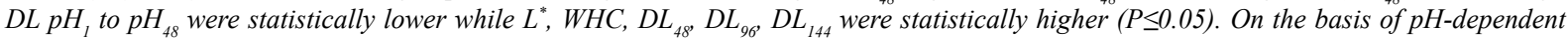
methods classification to RFN (red, firm, normal), PSE (pale, soft, exudative), DFD (dark, firm, dry) and AM (acid meat) was performed and then the percentage share of Low DL and High DL among meat classified as RFN was evaluated. Despite most samples were classified as RFN Low DL share among them did not exceed 50\%. If meat sample shows metabolites concentration below threshold value and was assigned to Low DL (or was assigned to High DL above threshold value) it was regarded as correctly classified. The most promising cut-off point (correct classification of 73\%) was 45 umol both for glycogen and lactate.

Key words: drip loss, glycogen, lactate, $\mathrm{pH}$, pork quality.

Precisão da classificação de métodos de avaliação da qualidade da carne suína para menor perda durante o gotejamento

RESUMO: Neste estudo foram analisadas 100 amostras de longissimus dorsi $(L D)$ de suinos Landrace, Yorkshire $(L \times Y) \times$ Duroc $(D)$. Dois grupos foram distinguidos de acordo com a perda por gotejamento medida 48 horas após o abate, por ex. DL baixo (DL $\left.{ }_{48} \leq \%\right)$ e $D L$ alto $\left(D L_{48}>4 \%\right)$. Em DL alto maior leveza $\left(L^{*}\right)$, capacidade de retenção de água $(W H C)$, perda por gotejamento em $48\left(D L_{48}\right), 96\left(D L_{90}\right)$, $144\left(D L_{144}\right)$ e menor acidez muscular de 35 min. a 48 horas post mortem $\left(\mathrm{pH}_{1}\right.$ a $\left.\mathrm{pH}_{48}\right)$ foram anotados $(P \leq 0.01)$. A baixa participação de $D L$ dentro das amostras classificadas como RFN (vermelha, firme, normal) com base em vários métodos de avaliação da qualidade da carne suina usando diferentes pontos de tempo de $\mathrm{pH}$ e valores de limiar não excederam $50 \%$. A tentativa de uso de várias concentrações de metabólitos musculares mediu 45 min. post mortem (glicogênio, lactato e suas combinações) como valores limiares na avaliação de DL baixo e DL alto foi então realizado. Os pontos de corte mais promissores (45 $\mu$ mol por $g$ de tecido muscular tanto para glicogênio quanto para lactato) permitiram classificar corretamente $83.82 \%$ de DL baixo e $50 \%$ de DL alto respectivamente abaixo e acima deles.

Palavras-chave: perda por gotejamento, glicogênio, lactato, $p H$, qualidade da carne suína.

\section{INTRODUCTION}

According to JOO et al. (2013) modern consumers demands for high meat quality still increase so this needs should be fulfilled with consistent production of tasty, safe and healthy products that will ensure continuous consumption in future. Nowadays both in Europe and in the US the majority of purchased meat (that is still rising) is unprocessed, e.g. fresh (DANIEL et al., 2011). Undoubtedly one of the most important attributes of fresh pork besides its colour, texture and amount of fat (intramuscular/ intermuscular/subcutaneous) is drip loss that occurs during muscle to meat conversion (JOO et al., 2013). Because of consumer demands it should be minimized to reduce negative impact to appearance and sensory quality of meat that it generates (TROY \& KERRY, 2010). Decrease in exudation is also of great interest for the retail market due to display time elongation of case-ready meat products (OTTO 
et al., 2007). Excessive drip loss in fresh pork also lowers technological quality, i.e. processing yield that generates considerable financial losses borne by the processors (HUFF-LONERGAN \& LONERGAN, 2007). According to FISCHER (2007) in Germany per $1 \%$ of excessive drip loss in pork loin financial losses of 19.8 million $€$ is generated annually and according to KNOX et al. (2008) the U.S. pork industry loses more than $\$ 100$ million annually due to quality defects.

In view of the above the correct prediction of fresh pork with low technological quality is of crucial importance; and therefore, different approaches was established to evaluate drip loss worldwide. Most of them cannot be used directly in the abattoir and are executed after 24 hours post mortem so their usefulness in sorting of carcasses is low (PRANGE et al., 1977; KAUFFMAN, 1993; CHRISTENSEN, 2003; CORREA, 2007; KAPPER et al., 2014). Significant differences in results between these methods are also observed due to various procedures used (FILHO et al., 2017). It is also common to classify pork into quality classes (PSE - pale, soft, exudative; RFN - red, firm, nonexudative; DFD - dark, firm, dry and AM - acid meat) on the basis of several criteria measured up to 24 hours after slaughter but both selection of these criteria and their threshold values differ amongst most countries (KAUFFMAN et al., 1993; RAUW et al., 2003; KOĆWIN-PODSIADŁA et al., 2006; FAUCITANO et al., 2010; POSPIECH et al., 2011; PRZYBYLSKI et al., 2012; TARCZYŃSKI et al., 2018; KIM et al., 2016). Therefore, the frequency distribution of pork quality classes could vary which was recently confirmed by CAZADEY et al. (2016). Anyway occurrence of pork with high drip loss is still a common phenomena (BARBUT et al., 2008; FAUCITANO et al., 2010; CAZADEY et al., 2016).

Muscle acidity (pH) decline and extent is generally accepted to be one of the most important factors connected with drip loss. Early $\mathrm{pH}$ measurements of pork could be used for carcass sorting but their application in abattoirs is rather limited (KOĆWIN-PODSIADŁA et al., 2006). Also, ultimate $\mathrm{pH}\left(\mathrm{pH}_{\mathrm{u}}\right)$ due to relatively late time of execution and probability of its elongation could also decrease its usefulness (TARCZYŃSKI et al., 2018). Conversely, muscle glycogen being converted post mortem to lactate and $\mathrm{H}^{+}$ions is also responsible for proper muscle acidification and highly determine $\mathrm{pH}$ decrease rate and extent (SCHEFFLER et al., 2013). This complex biochemical process known as glycogenolysis is the most crucial factor in muscle to meat conversion in which according to POSO \& PUOLANNE (2005) the carbohydrate metabolism is of the highest importance. However, there is still lack of knowledge about the potential usefulness of muscle metabolites concentration measured after slaughter for diagnostic purposes.

This study compared the diagnostic value of pork quality evaluation methods using different $\mathrm{pH}$ time-points and threshold values with different muscle metabolites concentration threshold values measured in pre-rigor state (glycogen, lactate and their combinations) in sorting of carcasses with lowered drip loss.

\section{MATERIALS AND METHODS}

\section{Animals, slaughter and carcass treatment}

The investigation was carried out in autumn on 100 (Landrace $\times$ Yorkshire $) \times$ Duroc fatteners $(50$ gilts and 50 barrows) originated from one producer (Mazowsze district, Poland). At the farm, animals were kept under the same environmental conditions (concrete floor) and fed complete diet according to age with ad libitum water accessibility. After reaching a body weight of about $105 \mathrm{~kg}$ fatteners were loaded (no electrical pods were used) in small groups by qualified personnel to transport vehicles. The transport was performed at night (approximately for $280 \mathrm{~km}$ ). After unloading in meat plant animals were moved to large pens for 4 hours rest with easy access to fresh water and afterwards moved to stunning area by trained personnel using paddles and hydraulically powered restraint equipment. Fatteners were stunned using automatic electrical stunner (MIDAS, Stork RMS, the Netherlands and INARCO constant voltage system) and exsanguinated horizontally in accordance with the meat plant technology. Lean meat content was determined 35 min post mortem by ULTRA-FOM 300 (SFK-Technology) and hot carcass weight $(\mathrm{HCW})$ was measured immediately afterwards (accuracy up to $0.1 \mathrm{~kg}$ ). Subsequently, carcasses were chilled in three-phase chilling tunnel $\left(-10{ }^{\circ} \mathrm{C}\right.$ for $15 \mathrm{~min} .,-15{ }^{\circ} \mathrm{C}$ for $25 \mathrm{~min}$. and $-5{ }^{\circ} \mathrm{C}$ for $40 \mathrm{~min}$. with air velocity of $3 \mathrm{~m} / \mathrm{s}$ ) and stored at $4{ }^{\circ} \mathrm{C}$ up to $24 \mathrm{~h}$ after slaughter.

\section{Meat quality attributes}

All of examined meat quality attributes were measured directly in hanging carcasses in the longissimus lumborum muscle (LL) behind the last rib (from $35 \mathrm{~min}$. to $24 \mathrm{~h}$ post mortem) or in meat samples taken at last rib and $1^{\text {st }}$ lumbar vertebra (after 24 hour after slaughter). Each of muscle sample was 
separated from the bone, external fat and epimysium and then stored in plastic bags at $0-4{ }^{\circ} \mathrm{C}$. Acidity of muscle tissue ( $\mathrm{pH}$ ) was measured $35 \mathrm{~min} ., 2 \mathrm{~h}, 3 \mathrm{~h}, 24$ $\mathrm{h}$ and $48 \mathrm{~h}\left(\mathrm{pH}_{1}, \mathrm{pH}_{2}, \mathrm{pH}_{3}, \mathrm{pH}_{24}\right.$ and $\mathrm{pH}_{48}$ respectively) using a pistol pH-meter MASTER (Draminski, Olsztyn, Poland) with temperature compensation. Water-holding capacity (WHC) was measured after 24 hours by the filter paper press method (Whatman 4 filter paper) according to GRAU \& HAMM method (1953) modified by POHJA \& NINIVAARA (1957). Drip loss was assessed $48 \mathrm{~h}, 96 \mathrm{~h}$ and $144 \mathrm{~h}\left(\mathrm{DL}_{48}\right.$, $\mathrm{DL}_{96}, \mathrm{DL}_{144}$ respectively) according to PRANGE et al. (1977). Meat color lightness $\left(\mathrm{L}^{*}\right)$ and its components $\left(a^{*}\right.$ - red and $b^{*}$ - yellow) was measured $24 \mathrm{~h}$ with a Minolta Chroma Meter (model CR 310, Minolta, Osaka, Japan) using D65 illuminant and $50 \mathrm{~mm}$ orifice. Meat yield after curing and thermal processing in $72{ }^{\circ} \mathrm{C}$ was expressed by the TY (technological yield) indicator according to NAVEAU et al. (1985).

\section{Muscle metabolites concentration}

Immediately after $\mathrm{pH}_{1}$ measurement LL muscle samples (1 g per carcass) were taken and immersed (up to $45 \mathrm{~min}$. post mortem) into tubes with $10 \mathrm{ml}$ of $0.5 \mathrm{M} \mathrm{HCLO}_{4}$ and then homogenized to inhibit glycogen changes in muscles. Samples were stored at $-20{ }^{\circ} \mathrm{C}$ for 3 weeks. Glycogen concentration was determined by enzymatic method according to DALRYMPLE \& HAMM (1973) using amyloglucosidase derived from the yeast Aspergillus niger. Lactate concentration was determined according to BERGMEYER (1978) using lactate dehydrogenase. The glycolytic potential (GP) was calculated as the sum of: 2 [glycogen] + [lactate] according to simplified formula of MONIN $\&$ SELLIER (1985) and expressed as $\mu \mathrm{mol}$ of lactic acid equivalent per $\mathrm{g}$ of fresh muscle tissue.

\section{Polymorphism of RYR1 gene}

The genomic DNA was isolated from white blood cells according to KAWASAKI (1990). RYR1 C1843T polymorphic site was analysed with DNA test using the PCR/RFLP method according to FUJII et al., (1991). No $R Y R I^{\mathrm{T}} R Y R I^{\mathrm{T}}$ genotypes were diagnosed.

\section{Meat quality evaluation methods}

In this study the comparison of pork quality evaluation methods using different $\mathrm{pH}$ threshold values and time-points with muscle metabolites concentration threshold values measured $45 \mathrm{~min}$. post mortem in assessment of meat with lowered drip loss was performed. In table $1 \mathrm{pH}$-dependent methods were shown (different $\mathrm{pH}$ threshold values and time-points) while muscle metabolites

Table 1 - Pork quality evaluation methods using different $\mathrm{pH}$ time-points and threshold values.

\begin{tabular}{|c|c|c|c|c|c|c|c|c|}
\hline \multirow{2}{*}{$\begin{array}{l}\text { Meat quality } \\
\text { class }\end{array}$} & & - & -----Evalu & n methods----. & 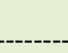 & 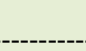 & ----------- & \multirow{2}{*}{$\begin{array}{l}\text { Time- } \\
\text { points }\end{array}$} \\
\hline & $\begin{array}{c}\text { RAUW } \\
\text { et al., } 2003 \\
\text { pHI }\end{array}$ & $\begin{array}{c}\text { PRZYBYLSKI } \\
\text { et al., } 2012 \\
\text { pHII }\end{array}$ & $\begin{array}{c}\text { POSPIECH } \\
\text { et al., } 2011 \\
\text { pHIII }\end{array}$ & $\begin{array}{c}\text { KOĆWIN- } \\
\text { PODSIADŁA, } \\
2006 \\
\text { pHIV }\end{array}$ & $\begin{array}{l}\text { PIC, } \\
2003 \\
\text { pHV }\end{array}$ & $\begin{array}{c}\text { PIC, } \\
2003 \\
\mathrm{pHV}^{\mathrm{m} 1}\end{array}$ & $\begin{array}{c}\text { PIC, } \\
2003 \\
\text { pHV }^{\mathrm{m} 2}\end{array}$ & \\
\hline \multirow{2}{*}{ RFN } & $\geq 6.00$ & $\begin{array}{l}\geq 6.0 \\
\geq 60\end{array}$ & $>{ }_{*}+5.8$ & $\geq \underset{*}{26.0}$ & $\begin{array}{c}6.3- \\
6.7 \\
*\end{array}$ & $\begin{array}{c}6.3- \\
6.7 \\
*\end{array}$ & $\begin{array}{l}* \\
*\end{array}$ & \multirow{10}{*}{$\begin{array}{l}\mathrm{pH}_{1} \\
\mathrm{pH}_{3} \\
\mathrm{pH}_{24}\end{array}$} \\
\hline & $5.30-6.20$ & $\geq 5.5-<5.8$ & $5.5-6.0$ & $5.5-6.0$ & $\begin{array}{c}5.7- \\
6.1\end{array}$ & $\begin{array}{c}5.5- \\
6.1\end{array}$ & $5.7-6.1$ & \\
\hline \multirow{2}{*}{ PSE } & $<\underset{*}{6.20}$ & $<6.0$ & $\leq 5.8$ & $<6.0$ & $<5.8$ & $<5.8$ & * & \\
\hline & $5.60-5.99$ & $*$ & $<5.5$ & $<5.5$ & $<5.5$ & $<5.5$ & * & \\
\hline \multirow{3}{*}{ DFD } & $\geq 6.00$ & * & $>6.0$ & $\geq 6.0$ & $>6.7$ & $>6.7$ & * & \\
\hline & $*$ & $*$ & * & $*$ & $*$ & * & * & \\
\hline & $>6.20$ & * & $>6.0$ & $\geq 6.0$ & $>6.1$ & $>6.1$ & * & \\
\hline \multirow{3}{*}{ AM } & * & $\geq 6.0$ & * & $\geq 6.0$ & $*$ & * & $*$ & \\
\hline & $*$ & $\geq 6.0$ & * & $*$ & $*$ & $*$ & $*$ & \\
\hline & $<5.30$ & $<5.5$ & * & $<5.5$ & $*$ & * & * & \\
\hline
\end{tabular}

* - no threshold value assigned; $\mathrm{m}$ - modified. 
concentration threshold values measured $45 \mathrm{~min}$. post mortem were presented in table 2 . To verify the accuracy of examined evaluation methods two groups regarding drip loss measured 48 hour post mortem were distinguished, e.g. Low DL - $\mathrm{DL}_{48} \leq 4 \%$ and High DL $-\mathrm{DL}_{48} \geq 4 \%$ and characterized by quality attributes described in previous section. In case of $\mathrm{pH}$ dependent methods the classification to RFN, PSE, DFD and AM was performed. Taking into account that sample classified as RFN may not necessarily stand for lowered drip loss the percentage share of Low DL and High DL within meat classified as RFN was carried out. If $\mathrm{pH}$ of certain sample did not fulfil threshold values or certain class was not assessable by examined method it was regarded as unclassified. The attempt of assessment of meat samples with lowered drip loss using muscle metabolites, e.g. glycogen and lactate concentration was performed on the basis of their strict threshold values (cut-off points). If meat sample shows muscle metabolites concentration below certain threshold value and simultaneously was assigned to Low DL it was regarded as correctly classified. If muscle metabolites concentration was above certain threshold value and simultaneously assigned to High DL it was also regarded as correctly classified. The aforementioned attempt allowed to eliminate possibility of improper classification of meat samples to High DL below respective threshold values and to Low DL above them. Muscle metabolites threshold levels, e.g. glycogen and lactate were examined solely and in combinations.

\section{Statistical analysis}

Data were analysed by one-way analysis of variance using non-orthogonal contrast in STATISTICA 13.1 (StatSoft, Tulsa, OK, USA). The model was expressed as follows: $y_{i}=\mu+a_{i}+e_{i}\left(y_{i}\right.$ - measured $i_{\text {th }}$ trait, $\mu$ - overall population mean, $a_{i}$ analysed factor effect of $i_{\text {th }}$ trait, $e_{i}$ - random error). The significance of differences between means was calculated using Tukey's test.

\section{RESULTS}

\section{Carcass characteristics and meat quality attributes}

All research material was characterized by lean meat content of $58.4 \pm 2.32 \%$ with hot carcass weight of $86.2 \pm 3.27 \mathrm{~kg}$ (Table 3). No statistical differences in HCW, lean meat content, $\mathrm{a}^{*}, \mathrm{~b}^{*}, \mathrm{TY}$ and glycogen concentration were reported between Low DL and High DL groups. Statistically lower $(\mathrm{P} \leq 0.05) \mathrm{pH}_{1}$ to $\mathrm{pH}_{48}$, glycolytic potential and lactate concentration and higher lightness $\left(\mathrm{L}^{*}\right), \mathrm{WHC}, \mathrm{DL}_{48}, \mathrm{DL}_{96}$ and $\mathrm{DL}_{144}$, values were noted in High DL (Table 3).

\section{Classification to meat quality classes and accuracy in drip loss evaluation}

On the basis of $\mathrm{pH}$-dependent pork quality evaluation methods high percentage of RFN meat, e.g. $100 \%$ in pHI, $92 \%$ in pHII, $98 \%$ in $\mathrm{pHIII}$ and $\mathrm{pHIV}$ and $78 \%$ in $\mathrm{pHV}^{\mathrm{m} 1}$ was classified (Table 4 ). The threshold value for $\mathrm{pH}_{24}$ of abovementioned methods was 5.5. The main difference to these results was only $36 \%$ of meat samples classified as RFN with $\mathrm{pHV}$ in which $\mathrm{pH}_{24}$ threshold was higher (5.7) and $47 \%$ in $\mathrm{pHV}^{\mathrm{m} 2}$ in which $\mathrm{pH}_{1}$ was excluded (Table 4). Although, most of meat samples were classified as RFN with pHI, pHII, pHIII, pHIV and $\mathrm{pHV}^{\mathrm{m} 1}$ very limited share of Low DL were noted within them $(33 \%, 35.87 \%, 32.65 \%, 32.65 \%$ and $32.05 \%$ respectively). More accurate methods in assessment of pork with lowered drip loss were $\mathrm{pHV}$ and $\mathrm{pHV}^{\mathrm{m} 2}$ (44.44\% and $46.68 \%$ of Low DL share respectively). Pork samples correctly classified as Low DL below analysed muscle metabolites threshold values ranged from $25 \%$ in G35 to $56.25 \%$ in G45 and from 40.63 in L35 to $90.63 \%$ in L50 (Table 1). Irreversibly, the correctly classified High DL samples above examined cut-off points decreased from $89.71 \%$ in G45 to $48.82 \%$ in G35 and from $77.94 \%$ in L50 to $19.12 \%$ in $\mathrm{L} 35$. The highest correctly classified Low DL share below and High DL above combined glycogen and lactate threshold values was $83.82 \%$

Table 2 - Pork quality evaluation methods using muscle metabolites concentration threshold values measured 45 min. post mortem.

\begin{tabular}{lcr}
\hline & Muscle metabolites concentration threshold values measured 45 min. post mortem [ $\mu$ mol per g of muscle tissue) \\
\hline Glycogen & Lactate & Glycogen/Lactate \\
\hline 35 (G35) & $35(\mathrm{~L} 35)$ & $40 / 40(\mathrm{G} 40 / \mathrm{L} 40)$ \\
40 (G40) & $40(\mathrm{~L} 40)$ & $40 / 45(\mathrm{G} 40 / \mathrm{L} 45)$ \\
45 (G45) & $45(\mathrm{~L} 45)$ & $45 / 40(\mathrm{G} 45 / \mathrm{L} 45)$ \\
& $50(\mathrm{~L} 50)$ & $45 / 45(\mathrm{G} 45 / \mathrm{L} 50)$ \\
\hline
\end{tabular}

Ciência Rural, v.51, n.10, 2021. 
Table 3 - Carcass characteristics, meat quality attributes and muscle metabolites measured 45 min post mortem.

\begin{tabular}{|c|c|c|c|c|}
\hline \multirow[t]{2}{*}{ Traits } & \multicolumn{3}{|c|}{------------------------------------Groups------------------------------------- } & \multirow[t]{2}{*}{$\mathrm{P}$} \\
\hline & Low DL & High DL & Total & \\
\hline $\mathrm{HCW}[\mathrm{kg}]$ & $85.8 \pm 3.34$ & $86.9 \pm 3.90$ & $86.2 \pm 3.72$ & 0.32 \\
\hline Lean meat content $[\%]$ & $58.1 \pm 2.05$ & $58.5 \pm 2.44$ & $58.4 \pm 2.32$ & 0.76 \\
\hline $\mathrm{pH}_{1}$ & $6.6 \pm 0.11^{\mathrm{a}}$ & $6.5 \pm 0.15^{\mathrm{b}}$ & $6.6 \pm 0.15$ & 0.01 \\
\hline $\mathrm{pH}_{2}$ & $6.5 \pm 0.1^{\mathrm{a}}$ & $6.4 \pm 0.19^{\mathrm{b}}$ & $6.5 \pm 0.18$ & 0.03 \\
\hline $\mathrm{pH}_{3}$ & $6.4 \pm 0.1^{\mathrm{a}}$ & $6.2 \pm 0.20^{\mathrm{b}}$ & $6.3 \pm 0.19$ & 0.05 \\
\hline $\mathrm{pH}_{24}$ & $5.7 \pm 0.1^{\mathrm{a}}$ & $5.6 \pm 0.09^{\mathrm{b}}$ & $5.7 \pm 0.11$ & $<0.00$ \\
\hline $\mathrm{pH}_{48}$ & $5.5 \pm 0.1^{\mathrm{a}}$ & $5.5 \pm 0.09^{b}$ & $5.5 \pm 0.10$ & $<0.00$ \\
\hline $\mathrm{L}^{*}$ & $53.5 \pm 2.79^{\mathrm{b}}$ & $55.0 \pm 2.6^{\mathrm{a}}$ & $54.5 \pm 2.75$ & 0.04 \\
\hline$a^{*}$ & $13.8 \pm 1.45$ & $14.2 \pm 1.20$ & $14.0 \pm 1.29$ & 0.18 \\
\hline$b^{*}$ & $4.7 \pm 1.29$ & $5.1 \pm 1.20$ & $4.5 \pm 1.24$ & 0.75 \\
\hline TY [\%] & $100.8 \pm 7.21$ & $101.4 \pm 7.28$ & $101.2 \pm 7.23$ & 0.31 \\
\hline $\mathrm{WHC}\left[\mathrm{cm}^{2}\right]$ & $4.5 \pm 1.13^{\mathrm{b}}$ & $5.4 \pm 1.1^{\mathrm{a}}$ & $5.1 \pm 1.22$ & 0.02 \\
\hline $\mathrm{DL}_{48}[\%]$ & $2.8 \pm 0.88^{\mathrm{b}}$ & $6.7 \pm 2.3^{\mathrm{a}}$ & $5.4 \pm 2.69$ & $<0.00$ \\
\hline $\mathrm{DL}_{96}[\%]$ & $6.0 \pm 1.42^{\mathrm{b}}$ & $9.8 \pm 2.3^{\mathrm{a}}$ & $8.5 \pm 2.74$ & $<0.00$ \\
\hline $\mathrm{DL}_{144}[\%]$ & $8.7 \pm 2.39^{b}$ & $12.0 \pm 2.6^{\mathrm{a}}$ & $10.9 \pm 3.02$ & $<0.00$ \\
\hline Glycolytic potential $[\mu \mathrm{mol} / \mathrm{g}]$ & $126.5 \pm 25.40^{\mathrm{b}}$ & $136.4 \pm 18.00^{\mathrm{a}}$ & $133.3 \pm 20.99$ & 0.04 \\
\hline Glycogen concentration $[\mu \mathrm{mol} / \mathrm{g}]$ & $44.2 \pm 11.50$ & $47.0 \pm 9.99$ & $46.1 \pm 10.51$ & 0.16 \\
\hline Lactate concentration $[\mu \mathrm{mol} / \mathrm{g}]$ & $38.0 \pm 8.57^{\mathrm{b}}$ & $42.4 \pm 9.00^{\mathrm{a}}$ & $41.0 \pm 9.05$ & 0.04 \\
\hline
\end{tabular}

Values were presented as means and standard deviations $( \pm \mathrm{SD})$; Means followed by different letters on the same line are significantly different by Tukey's test at 5\% probability level.

and $50 \%$ respectively $(\mathrm{G} 45 / \mathrm{L} 45)$ that resulted in $73 \%$ of overall correct classification (Table 5).

\section{DISCUSSION}

Carcass characteristics, meat quality traits and muscle metabolites concentration

No statistical differences noted in lean meat content and hot carcass weight between Low
DL and High DL were in accordance with study of TRAORE et al. (2012). It has to be stated though that cited authors found experimental group with $\mathrm{DL}_{48}>4 \%$ approximately $8 \mathrm{~kg}$ lower in HCW besides similar $\mathrm{DL}_{48}$ mean value $(7.72 \%)$ to our findings for High DL. In study of RYBARCZYK et al. (2018) similar $\mathrm{pH}$ measured $35 \mathrm{~min}(6.58 \pm 0.15)$ and 24 hours $(5.65 \pm 0.16)$ after slaughter were reported in (Landrace $\times$ Yorkshire $) \times$ DanAvl Duroc. However

Table 4 - Classification to meat quality classes on the basis of different $\mathrm{pH}$ time-points and threshold values along with Low DL share within meat classified as RFN.

\begin{tabular}{|c|c|c|c|c|c|c|c|}
\hline \multirow[t]{2}{*}{ Meat quality classes } & \multicolumn{7}{|c|}{ 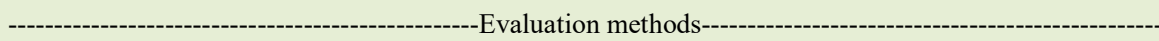 } \\
\hline & $\mathrm{pHI}$ & pHII & pHII & pHIV & $\mathrm{pHV}$ & $\mathrm{pHV}^{\mathrm{m} 1}$ & $\mathrm{pHV}^{\mathrm{m} 2}$ \\
\hline $\begin{array}{l}\text { RFN [\%] } \\
\text { Low DL [\%] }\end{array}$ & $100(33)$ & $92(35.87)$ & $98(32.65)$ & $98(32.65)$ & $36(44.44)$ & $78(32.05)$ & $47(46.68)$ \\
\hline PSE [\%] & 0 & 0 & 0 & 0 & 0 & 0 & * \\
\hline DFD [\%] & 0 & 0 & 1 & 1 & 0 & 0 & * \\
\hline $\mathrm{AM}[\%]$ & 0 & 1 & $*$ & 1 & $*$ & $*$ & * \\
\hline Unclassified [\%] & 0 & 7 & 1 & 0 & 64 & 22 & 53 \\
\hline
\end{tabular}

* - no threshold values assigned; RFN - red, firm, non-exudative, PSE - pale, soft, exudative; DFD - dark, firm, dry, AM - acid meat; Low $\mathrm{DL}$ - drip loss measured 48 hours post mortem $\leq 4 \%$.

Ciência Rural, v.51, n.10, 2021. 
Table 5 - Correct classification to Low DL and High DL on the basis of different threshold level values of glycogen, lactate and their combinations.

\begin{tabular}{|c|c|c|c|}
\hline $\begin{array}{l}\text { Muscle metabolites threshold } \\
\text { values }\end{array}$ & $\begin{array}{l}\text { Correct classification to Low } \\
\text { DL below threshold value }\end{array}$ & $\begin{array}{l}\text { Correct classification to High } \\
\text { DL above threshold value }\end{array}$ & Correct classification (overall) \\
\hline G35 & $25.00 \%$ & $89.71 \%$ & $69.00 \%$ \\
\hline G40 & $43.75 \%$ & $76.47 \%$ & $66.00 \%$ \\
\hline G45 & $56.25 \%$ & $48.82 \%$ & $58.00 \%$ \\
\hline L35 & $40.63 \%$ & $77.94 \%$ & $65.00 \%$ \\
\hline L40 & $40.63 \%$ & $61.76 \%$ & $60.00 \%$ \\
\hline L45 & $84.38 \%$ & $41.18 \%$ & $55.00 \%$ \\
\hline L50 & $90.63 \%$ & $19.12 \%$ & $42.00 \%$ \\
\hline G40/L45 & $37.50 \%$ & $92.50 \%$ & $75 \%$ \\
\hline G40/L50 & $40.63 \%$ & $83.82 \%$ & $70 \%$ \\
\hline G45/L45 & $83.82 \%$ & $50.00 \%$ & $73 \%$ \\
\hline G45/L50 & $67.65 \%$ & $53.13 \%$ & $43 \%$ \\
\hline
\end{tabular}

Low DL - drip loss measured 48 hours post mortem $\leq 4 \%$; High DL - drip loss measured 48 hours post mortem $>4 \%$; $\mathrm{G}$-glycogen concentration measured $45 \mathrm{~min}$ post mortem expressed in $\mu \mathrm{mol}$ per $\mathrm{g}$ of muscle tissue, $\mathrm{L}$ - lactate concentration measured 45 min post mortem expressed in $\mu$ mol per $\mathrm{g}$ of muscle tissue.

cited authors noted lower $\mathrm{pH}_{3}(5.91 \pm 0.19)$ and higher $\mathrm{pH}_{48}(5.72 \pm 0.20)$ and $\mathrm{pH}_{96}(5.68 \pm 0.14)$. Lower $\mathrm{pH}_{1}$ (5.86 \pm 0.18$)$ and $\mathrm{pH}_{24}(5.51 \pm 0.01)$ were also noted by ZENG et al. $(2019)$ in (Landrace $\times$ Yorkshire) $\times$ Duroc. Abovementioned could possibly occur due to differences in carcass cooling regime (in present survey three-phase chilling tunnel was used). Contrary to our findings KAPPER et al. (2014) reported no statistical differences in $\mathrm{pH}_{1}$ between experimental groups differentiated by $\mathrm{DL}_{48}$ level. Cited authors found instead statistically lower $\mathrm{pH}_{3}$ and $\mathrm{pH}_{24}(\mathrm{P} \leq 0.05)$ in meat samples with $\mathrm{DL}_{48}$ above $10 \%$. In our study; however, such high drip loss occurrence was very limited. TRAORE et al. (2012) found no differences in $\mathrm{pH}_{1}, \mathrm{pH}_{3}$ and $\mathrm{pH}_{24}$ between pork samples differentiated by $\mathrm{DL}_{48}$ level in Naïma $\times$ P76 fatteners. In contrast, KIM et al. (2016) reported higher $\mathrm{DL}_{48}(\mathrm{P} \leq 0.05)$ in Berkshire fatteners if $\mathrm{pH}_{1}$ was below 6.3 and that higher $\mathrm{DL}_{48}$ was strictly associated with lower $\mathrm{pH}_{24}$. The aforementioned could possibly indicate that $\mathrm{pH}$ use in pork quality evaluation could be additionally limited due to different results depending on pig breed. Slightly higher values of $\mathrm{L}^{*}(55.24 \pm 2.78)$ and notably lower $\mathrm{a}^{*}(5.10 \pm 1.06)$ and higher $\mathrm{b}^{*}(13.34 \pm 0.60)$ were reported by RYBARCZYK et al. (2018). ZENG et al. (2019) found lower $L^{*}(50.98 \pm 0.64)$ and $a^{*}$ $(6.51 \pm 0.58)$ with similar $b^{*}(4.90 \pm 0.25)$. TRAORE et al. (2012) found rather weak statistical differences $(\mathrm{P}<0.0663)$ in meat lightness between different $\mathrm{DL}_{48}$ ranges among Naïma $\times$ P76 fatteners. Similarly to our findings no statistical differences in $\mathrm{a}^{*}$ were found. In study of RYBARCZYK et al. (2018) and ZENG et al. (2019) lower values of $\mathrm{DL}_{48}$ were noted $(2.19 \pm 0.99 \%$ and $2.83 \pm 0.19 \%$ respectively). However in present survey $\mathrm{DL}_{48}$ value was $5.44 \pm 2.69 \%$ which confirms that variability in pork drip loss is rather high.

\section{Evaluation methods using different $p H$ time-points and threshold values}

According to BOLER et al. (2010) one of the main goals of pork industry is to improve, predict and reduce variation in pork quality. Due to fact, that several quality attributes of fresh pork including colour, WHC and drip loss are determined by muscle $\mathrm{pH}$ fall and extent its measurement at different time-points after slaughter is widely used for quality evaluation. SCHAFER et al. (2002) reported that variation in $\mathrm{pH}$ measured up to 24 hours after slaughter determine $90 \%$ of variation in $\mathrm{DL}_{48}$. In study of FISHER (2007) $75 \%$ of carcasses could be correctly classified regarding drip loss amount by $\mathrm{pH}_{1}$ threshold value of 6.2. However, in present study the highest share of Low DL within meat samples classified as RFN on the basis of remain $\mathrm{pH}$-dependent methods (including $\mathrm{pH}_{1}$ and $\mathrm{pH}_{3}$ ) did not exceed $50 \%$ (Table 4). This could possibly indicate that measurement of $\mathrm{pH}$ fall and extent only is not sufficient for proper quality evaluation due to complexity of post mortem muscle metabolism. Additionally BOLER et al. (2010) 
suggested that $\mathrm{pH}_{1}$ and $\mathrm{pH}_{3}$ are of low predictive value if analysed population is characterised by small variation. As reported by cited authors low values of $\mathrm{pH}_{1}$ and $\mathrm{pH}_{3}$ may also not always correspond to quality deterioration; therefore, $\mathrm{pH}_{24}$ is much better parameter in prediction of pork quality. This is partly in accordance with our findings: both Low DL and High DL experimental groups were characterised by rather high $\mathrm{pH}_{1}, \mathrm{pH}_{2}$ and $\mathrm{pH}_{3}$ values; however, $\mathrm{pH}_{24}$ solely $\left(\mathrm{pHV}^{\mathrm{m} 2}\right)$ allows to differentiate $32 \%$ of RFN meat among with only $46.88 \%$ were correctly classified to Low DL (Table 4). Low predictive value of $\mathrm{pH}_{1}$ and $\mathrm{pH}_{24}$ in pork ultimate quality prediction was also noted by TOMOVIC et al. (2014).

\section{Evaluation methods using muscle metabolites levels} measured 45 min. post mortem

Although, muscle metabolites concentration highly determined pork quality attributes their whole potential in quality evaluation is not yet fully known. MATARNEH et al. (2015) show that variation in ultimate $\mathrm{pH}$ could be explained by differences in buffering capacity of muscle and indicated that additional $10 \mu \mathrm{mol}$ of lactate per $\mathrm{g}$ of muscle tissue produced during post mortem glycolysis reduce $\mathrm{pH}$ of muscle by 0.2 units. KOĆWIN-PODSIADŁA et al. (2009) noted that the increase in glycogen concentration measured $45 \mathrm{~min}$. after slaughter by $10 \mu \mathrm{mol}$ per $\mathrm{g}$ of muscle tissue resulted in considerable increase in $\mathrm{DL}_{48}$ and $\mathrm{DL}_{144}$ (by $0.9 \%$ and $1.6 \%$ respectively). Although, ZYBERT et al. (2020) reported no statistical differences in $\mathrm{DL}_{48}$ within three ranges of glycogen concentration measured $45 \mathrm{~min}$ after slaughter $(<35,35-55$ and $>55 \mu \mathrm{mol}$ per $\mathrm{g}$ of muscle tissue). In present study the highest share of correctly classified meat samples (to Low DL or High DL) on the basis of glycogen concentration was $69 \%$ (G35). This substantial value arises from meat samples correctly classified to High DL (89.71\%) but not to Low DL (37.50\%). Higher correct classifications of meat samples to Low DL were noted in G40 and G45 (43.75\% and 56.25\% respectively). Lactate concentration threshold values of 35 (L35) and 40 (L40) $\mu \mathrm{mol}$ per g of muscle tissue allowed to correctly classify meat samples in $65 \%$ and $60 \%$ respectively. Similarly to G35 these values arise from high share of correctly classified High DL (77.94\% and $61.76 \%$ respectively). With 45 (L45) and 50 (L50) $\mu \mathrm{mol}$ of lactate per $g$ of muscle tissue higher correctly classified shares of Low DL were achieved (respectively $84.38 \%$ and $90.63 \%$ ). Taking that into account it can be presumed that glycogen level is more useful in correct classification to High
DL while lactate concentration to Low DL. However, full efficiency is not ensured.

The most useful combination of glycogen and lactate concentration threshold values (G45/ L45) allows to correctly classify $83.82 \%$ of analysed meat samples to Low DL below and $50 \%$ to High DL above them with overall correct classification of $73 \%$ (c.a. 25 p.p. more than in $\mathrm{pHV}$ and $\mathrm{pHV}^{\mathrm{m} 2}$ ). Similarly SHAFER et al. (2002) reported that muscle metabolites did not explain entire variance in drip loss (glycogen concentration determine it in $73 \%$ and lactate concentration in $88 \%$ ). However in survey of TRAORE et al. (2012) no statistical differences in GP were noted between pork with $\mathrm{DL}_{48}$ below $2.8 \%$ and above 4\%. BERTOL et al. (2017) suggested, that $87.33 \%$ of correctly classified carcasses with $\mathrm{DL}_{48}$ below and above $6 \%$ is possible to evaluate on the basis of linear discriminant function using $\mathrm{HCW}$, backfat thickness and loin depth in conjunction with $\mathrm{pH}$ and temperature measured at $45 \mathrm{~min}$ after slaughter. Also, as reported by cited authors using adjusted regression equations on the basis of the same parameters $85.44 \%$ of correctly classified carcasses to $\mathrm{DL}_{48}$ threshold value of $6 \%$ and $80.32 \%$ to $\mathrm{DL}_{48}$ threshold value of $5 \%$ could be obtain. In study of KUSEC et al. (2007) pork loin samples with $\mathrm{DL}_{48}$ threshold value of $5 \%$ was correctly classified in $62.18 \%$ and $77.31 \%$ on the basis of discriminant analysis and cluster analysis respectively.

\section{CONCLUSION}

Share of pork quality classes evaluated on the basis of different $\mathrm{pH}$ time-points and threshold values varied in population of (Landrace $\times$ Yorkshire) $\times$ Duroc fatteners. Frequent occurring of RFN did not correspond with lowered drip loss (Low DL within this meat samples classified as RFN did not exceed $50 \%$ ). Therefore, $\mathrm{pH}$-dependent methods of pork quality evaluation should be at least revised for their appropriate use in modern pork industry. Higher share of correctly classified meat samples with $\mathrm{DL}_{48} \leq 4 \%$ was noted if muscle metabolites threshold values measured $45 \mathrm{~min}$. after slaughter were used. The most promising cut-off points were $45 \mu \mathrm{mol}$ per $\mathrm{g}$ of muscle tissue both for glycogen and lactate level that allowed to correctly classify $83.82 \%$ of Low DL and $50 \%$ of High DL. Thereby use of glycogen and lactate threshold values in pre-rigor state could possibly be profitable for meat plants due to increase in accuracy of properly sorted carcasses with lowered drip loss. The potential of muscle metabolites use in pork quality evaluation is then high. 


\section{DECLARATION OF CONFLICT OF INTEREST}

The authors declare no conflict of interest. The founding sponsors had no role in the design of the study nor in data collection, analyses and interpretation.

\section{AUTHORS' CONTRIBUTIONS}

All authors contributed equally for the conception and writing of the manuscript. All authors critically revised the manuscript and approved of the final version.

\section{REFERENCES}

BARBUT, S. et al. Progress in reducing the pale, soft and exudative (PSE) problem in pork and poultry meat. Meat Science, v.79, n.1, p.46-63, 2008. Available from: <https://doi.org/10.1016/j. meatsci.2007.07.031>. Accessed: May, 14, 2020. doi: 10.1016/j. meatsci.2007.07.031.

BERGMEYER, H. U. Methods of Enzymatic Analysis. Academic Press: New York. 1978.

BERTOL, M. T. et al. Swine carcasses classified by degree of exudation and marbling content. Pesquisa Agropecuaria Brasileira, v.52, n.2, p.121-128, 2017. Available from: <https:// doi.org/10.1590/s0100-204x2017000200006>. Accessed: May, 17, 2020. doi: 10.1590/s0100-204×2017000200006.

BOLER, D. D. et al. Ultimate $\mathrm{pH}$ explains variation in pork quality traits. Journal of Muscle Foods, v.21, n.1, p.119-130, 2010. Available from: $<$ https://doi.org/10.1111/j.1745-4573.2009.00171. $\mathrm{x}>$. Accessed: Jun. 5, 2020. doi: 10.1111/j.1745-4573.2009.00171.x.

CAZADEY, H. P. et al. Comparison of different criteria used to categorize technological quality of pork. Ciência Rural, v.46, n.12, p.2241-2248, 2016. Available from: <http://dx.doi. org/10.1590/0103-8478cr20160013>. Accessed: Jun. 14, 2020. doi: $10.1590 / 0103-8478 \mathrm{cr} 20160013$.

CHRISTENSEN, L. B. Drip loss sampling in porcine $\mathrm{m}$. longissimus dorsi. Meat Science, v.63, n.4, p.469-477, 2003. Available from: $<$ https://doi.org/10.1016/S0309-1740(02)00106-7>. Accessed: Feb. 22, 2020. doi: 10.1016/S0309-1740(02)00106-7.

CORREA, J. A. et al. A modified meat juice container (EZDripLoss) procedure for a more reliable assessment of Drip Loss and related quality changes in pork meat. Journal of Muscle Foods, v.18, n.1, p.67-77, 2007. Available from: $<$ https://doi.org/1 0.1111/j.1745-4573.2007.00066.x>. Accessed: Mar. 25, 2020. doi: 10.1111/j.1745-4573.2007.00066.x.

DALRYMPLE, R. H.; HAMM, R. A method for the extraction of glycogen and metabolites from a single muscle sample. Journal of Food Technology, v.8, n.4, p.439-444, 1973. Available from: $<$ https://doi.org/10.1111/j.1365-2621.1973.tb01730.x>. Accessed: Feb. 25, 2019. doi: 10.1111/j.1365-2621.1973.tb01730.x.

DANIEL, C. R. et al. Trends in meat consumption in the United States. Public Health Nutrition, v.14, n.4, p.575-583, 2011. Available from: <https://doi.org/10.1017/S1368980010002077>. Accessed: Sep. 7, 2020. doi: 10.1017/S1368980010002077.
FAUCITANO, L. et al. Shelf life of pork from five different quality classes. Meat Science, v.84, n.3, p.466-469, 2010. Available from: $<$ https://doi.org/10.1016/j.meatsci.2009.09.017>. Accessed: Dec. 5, 2019. doi: 10.1016/j.meatsci.2009.09.017.

FILHO, R. D. A. T et al. Drip Loss Assessment by Different Analytical Methods and Their Relationships with Pork Quality Classification. Journal of Food Quality, v.6, p.1-8, 2017. Available from: <https://doi.org/10.1155/2017/9170768>. Accessed: Jul. 4, 2020. doi: 10.1155/2017/9170768.

FISCHER, K. Drip loss in pork: Influencing factors and relation to further meat quality traits. Journal of Animal Breeding and Genetics, v.124, n.s1, p.12-18, 2007. Available from: $<$ https://doi. org/10.1111/j.1439-0388.2007.00682.x>. Accessed: Jul. 4, 2020. doi: $10.1111 /$ j.1439-0388.2007.00682.x.

FUJII, J. et al. Identification of a mutation in porcine ryanodine receptor associated with malignant hyperthermia. Science, v.253, n.5018, p.448-450, 1991. Available from: <https://science. sciencemag.org/content/253/5018/448>. Accessed: Mar. 13, 2020. doi: $10.1126 /$ science. 1862346 .

GRAU, R.; HAMM, R. Eine einfache Methode zur Bestimmung der Wasserbindung in Muskel. Naturwissenschaften, v.4, p.29-30, 1953. Available from: <https://link.springer.com/article/10.1007/ BF00595734>.

HUFF-LONERGAN, E.; LONERGAN, S.M. New frontiers in understanding drip loss in pork: recent insights on the role of postmortem muscle biochemistry. Journal of Animal Breeding and Genetics, v.124, n.1, p.19-26, 2007. Available from: <https:// doi.org/10.1111/j.1439-0388.2007.00683.x>. Accessed: Jan. 22, 2019. doi: $10.1111 /$ j.1439-0388.2007.00683.x.

JOO, S. T. et al. Control of fresh meat quality through manipulation of muscle fiber characteristics. Meat Science, v.95, n.4, p.828-836, 2013. Available from: <https://doi.org/10.1016/j. meatsci.2013.04.044>. Accessed: Apr. 14, 2020. doi: 10.1016/j. meatsci.2013.04.044.

KAPPER, C. et al. Moisture absorption early postmortem predicts ultimate drip loss in fresh pork. Meat Science, v.96, n.2A, p. 971-976, 2014. Available from: <https://doi.org/10.1016/j. meatsci.2013.10.009>. Accessed: May, 5, 2020. doi: 10.1016/j. meatsci.2013.10.009.

KAUFFMAN, R. G. The effectiveness of examining early postmortem musculature to predict ultimate pork quality. Meat Science v.34, n.3, p.283-300, 1993. Available from: <https://doi. org/10.1016/0309-1740(93)90078-V>. Accessed: Nov. 15, 2019. doi: 10.1016/0309-1740(93)90078-V.

KAWASAKI, E. S. Sample preparation from blood cells and other fluids. In: INNIS, M.A; GELFAMD, D.H.; SNINSKY, J.J.; WHITE, T.J. PCR protocols: A guide to methods and applications. San Diego: Academic Press, 1990, p.146-152.

KIM, T. W. et al. Pork Quality Traits According to Postmortem pH and Temperature in Berkshire. Korean Journal for Food Science of Animal Resources, v.36, n. 1, p. 29-36, 2016. Available from: $<$ http://koreascience.or.kr/article/JAKO201607761295768.page>. Accessed: Nov. 15, 2019. doi: 10.5851/kosfa.2016.36.1.29.

KNOX, B. L. et al. Relationships between Ultimate $\mathrm{pH}$ and Microbial, Chemical, and Physical Characteristics of Vacuum- 
Packaged Pork Loins. Journal of Food Science, v. 73, n. 3, m104-m110, 2008. Available from: <https://doi.org/10.111 1/j.1750-3841.2008.00667.x>. Accessed: Jun. 3, 2020. doi: 10.1111/j.1750-3841.2008.00667.x.

KOĆWIN-PODSIADŁA, M. et al. Pork quality and methods of its evaluation - a review. Polish Journal of Food and Nutrition Sciences, v.56, n.3, p.241-248, 2006. Available from: <http:// journal.pan.olsztyn.pl/PORK-QUALITY-AND-METHODS-OFITS-EVALUATION-A REVIEW,97943,0,2.html>. Accessed: Jun. 27, 2020.

KOĆWIN-PODSIADŁA, M. et al. Glycogen content and the rate of glycolytic changes as the indicator of pork meat quality. In: 55th International Congress of Meat Science and Technology, 2009, Copenhagen, Prague. PE1.46. 2009. Available from: $<$ http://icomst-proceedings.helsinki.fi/papers/2009_01_54.pdfs. Accessed: Mar. 11, 2020.

KUSEC, G. et al. Discrimination between pork longissimus muscles with excessive and acceptable drip loss. In: 53rd International Congress of Meat Science and Technology, 2007, Beijing, China, v.4, p.67-68. Available from: <http://icomstproceedings.helsinki.fi/papers/2007 04 67.pdf $>$. Accessed: Mar. $11,2020$.

MATARNEH, S. K. et al. Net lactate accumulation and low buffering capacity explain low ultimate $\mathrm{pH}$ in the longissimus lumborum of AMPK $\gamma 3 \mathrm{R} 200 \mathrm{Q}$ mutant pigs. Meat Science, v.110, p.189-195, 2015. Available from: < https://doi.org/10.1016/j. meatsci.2015.07.023>. Accessed: Mar. 6, 2020. doi: 10.1016/j. meatsci.2015.07.023

MONIN, G.; SELLIER, P. Pork of low technological quality with a normal rate of muscle $\mathrm{pH}$ fall in the immediate post-mortem period: The case of the Hampshire breed. Meat Science, v.13, n.1, p.49-63, 1985. Available from: <https://doi.org/10.1016/S03091740(85)80004-8>. Accessed: Feb. 14, 2020. doi: 10.1016/S0309$1740(85) 80004-8$.

NAVEAU, J. et al. Proposition d'une méthode de mesuredu rendement technologique: la méthode Napole. Techni-Porc, v.8, p.7-13, 1985.

OTTO, G. et al. Different approaches of estimating economical values for drip loss as $\log$ normally distributed trait. Livestock Science, v.112, n.1-2, p.43-51, 2007. Available from: $<$ https://doi. org/10.1016/j.livsci.2007.01.155>. Accessed: May, 19, 2020. doi: 10.1016/j.livsci.2007.01.155.

PIC 2003. Pork Meat Quality: Understanding Industry Measurements and Guidelines. [2016-11-25]. Available from $<$ https://thepigsite.com/articles/pork-meat-quality-understandingindustry-measurements-and-guidelines $>$. Accessed: Feb. 7, 2020 doi: 10.1016/j.livsci.2007.01.155

POHJA, N. S.; NINIVAARA, F.P. Die Bestimmung der Wasserbindung des Fleisches mittels der Konsandrückmethods. Fleischwirtschaft, v.9, p.193-195, 1957.

POSO, A. R.; PUOLANNE E. Carbohydrate metabolism in meat animals. Meat Science, v.70, n3, p.423-434, 2005. Available from: $<$ https://doi.org/10.1016/j.meatsci.2004.12.017>. Accessed: May, 22, 2020. doi: 10.1016/j.meatsci.2004.12.017.
POSPIECH, E. et al. Meat defects and their characteristic. In: Pisula, A.; Pospiech, E. Meat - Science and technology base. Warsaw: SGGW Publisher, Warsaw, 2011, pp. 233-243.

PRANGE, H. et al. Untersuchung zur Muskelfleisch-qualität beim Schwein. 3. Mitt.: Bedeutung der Fleischtemperatur unter besonderer Berücksichtigung der Transportform. Archiv für Experimentelle Veterinär Medizin Leipzig, v.31, n.2, p.337, 1977.

PRZYBYLSKI, W. et al. Jakość technologiczna i sensoryczna wadliwego mięsa wieprzowego. ŻYWNOŚĆ. Nauka. Technologia. Jakość, v.1, n.80, p.116-127, 2012. Available from: $<\mathrm{http} / /$ bazekon.icm.edu.pl/bazekon/element/bwmeta1.element. ekon-element-000171309121>. Accessed: Apr. 21, 2020.

RAUW, W.M. et al. Meat production using four terminal pig lines. Journal of the Science of Food and Agriculture, v.83, n.14, p.1504-1510, 2003. Available from: <https://doi.org/10.1002/ jsfa.1568>. Accessed: May. 22, 2020. doi: 10.1002/jsfa.1568.

RYBARCZYK, A. et al. The effect of DanAvl Duroc and Pulawska boars in crossbred with DanAvl hybrid on meat quality of finishing pigs. Agricultural and Food Science, v.27, n.3, p.159-167, 2018. Available from: $<$ https://doi.org/10.23986/afsci.70934>. Accessed: May, 26, 2020. doi: 10.23986/afsci.70934.

SCHAFER, A. et al. Physiological and structural events post mortem of importance for drip loss in pork. Meat Science, v.61, n.4, p.355-366, 2002. Available from: $<$ https://doi.org/10.1016/S0309-1740(01)002054>. Accessed: Apr. 5, 2020. doi: 10.1016/S0309-1740(01)00205-4.

SCHEFFLER, T. L. High glycolytic potential does not predict low ultimate $\mathrm{pH}$ in pork. Meat Science, v.95, n.1, p. 85-91, 2013. Available from: <https://doi.org/10.1016/j.meatsci.2013.04.013>. Accessed: Apr. 5, 2020. doi: 10.1016/j.meatsci.2013.04.013.

TARCZYŃSKI, K. et al. pH measured 24 hours post mortem should not be regarded as ultimate $\mathrm{pH}$ in pork meat quality evaluation. South African Journal of Animal Science, v.48, n.6, p.1009-1016, 2018. Available from: <https://www.ajol.info/index.php/sajas/article/ view/183081>. Accessed: Sep. 3, 2020. doi: 10.4314/sajas.v48i6.2.

TRAORE, S. et al. Higher drip loss is associated with protein oxidation. Meat Science, v.90, n.4, p.917-924, 2012. Available from: $<$ https://doi.org/10.1016/j.meatsci.2011.11.033>. Accessed: Jun. 6, 2020. doi: 10.1016/j.meatsci.2011.11.033.

TROY,D. J.; KERRY, J.P. Consumerperception and the role of science in the meat industry. Meat Science, v.86, n.1, p.214-226, 2010. Available from: <https://doi.org/10.1016/j.meatsci.2010.05.009>. Accessed: Jun. 6, 2020. doi: 10.1016/j.meatsci.2010.05.009.

ZENG, Z. et al. Effect of dietary supplementation with mulberry (Morus alba L.) leaves on the growth performance, meat quality and antioxidative capacity of finishing pigs. Journal of Integrative Agriculture, v.18, n.1, p.143-151, 2019. Available from: <https:// doi.org/10.1016/S2095-3119(18)62072-6>. Accessed: Jun. 15, 2020. doi: 10.1016/S2095-3119(18)62072-6.

ZYBERT, A. et al. Relationship of glycogen and lactate concentrations as a pork quality indicator. South African Journal of Animal Science, v.50, n.1, p.26-37, 2020. Available from: $<$ https://www.ajol.info/index.php/sajas/article/view/194884>. Accessed: Jun. 15, 2020. doi: 10.4314/sajas.v50i1.4. 